\title{
The Memoirist against History: Nabokov's Speak, Memory as the (re)negotiation of a literary form at the intersection of personal experience and historical narrative
}

\author{
Michael Sala
}

University of Newcastle, Australia

\begin{abstract}
Nabokov's Speak, Memory is a literary memoir that negotiates the relationship between history and personal experience by illuminating one end of a spectrum of authoritative effects that range from artifice to spontaneity. In using play to leverage and highlight the tension between the artifice of a work of literature and the spontaneity of personal expression (or sense making on an individual level,) and by implicating both reader and writer within that tension, it demonstrates how literary memoir can negotiate its relationship to its genre. There are thus two forms of negotiation at work in Speak, Memory, the one between artifice and spontaneity, the other between individual experience and historical narrative. In this way, by using play to invite the reader into the interpretative act, Nabokov emphasises the role of artifice in the autobiographical project, and, by doing so, stakes out a claim for the literary autobiographical writer in the face of historical narrative.
\end{abstract}

Keyzords: Nabokov, history, memoir, artifice

One of the most studied episodes in Vladimir Nabokov's autobiographical work, Speak, Memory, is a sequence of events in the opening chapter unified by what the author describes as "the match stick theme." The episode involves two encounters with Alexey Nikolayevich Kuropatkin, a member of the old Russian aristocracy. During the first encounter, at the 
Nabokov family estate in pre-revolutionary Russia, Kuropatkin performs for Nabokov, six at the time, a simple trick with matches:

he spread out to amuse me a handful of matches, on the divan where he was sitting, placed ten of them end to end to make a horizontal line, and said, "This is the sea in calm weather." Then he tipped up each pair so as to turn the straight line into a zigzag-and that was "a stormy sea." He scrambled the matches and was about to do, I hoped, a better trick when we were interrupted. (Nabokov: 27)

This interruption is the news of Kuropatkin's appointment as supreme commander of the Russian Army in the Far East. The episode finds its sequel fifteen years later when Nabokov's father, fleeing Bolshevik Russia, encounters the general in peasant clothing attempting his own escape. The general no longer possesses even a single match, let alone armies, and asks Nabokov's father for one match with which to light his cigarette. Looking back on this, Nabokov writes:

I hope old Kuropatkin, in his rustic disguise managed to evade Soviet imprisonment, but that is not the point. What pleases me is the evolution of the match theme: those magic ones he had shown me had been trifled with and mislaid, and his armies had also vanished, and everything had fallen through, like my toy trains that, in the winter of 1904-1905, in Wiesbaden, I tried to run over the frozen puddles in the grounds of the Hotel Oranien. (Nabokov: 27)

The moment is often discussed because it forms part of Nabokov's explication of autobiographical method, or as Leland De La Durantaye puts it, his "programmatic statement" (166). This statement is, in Nabokov's typical style, delivered in the form-and simultaneous dramatisation-of play. Two incidents, fifteen years apart, are folded together into a single metaphorical development using match sticks. The match sticks may be interpreted as representing the triviality of human life as well as the ephemeral nature of power in the face of historical forces, and yet, in combination with the image of the boy playing with his toy train, which further couples these two incidents-notably in a train-like mannerwith an immediately preceding incident also involving a train; a newspaper depiction of real trains "made singularly toylike by the Japanese pictorial style" (26) a thematic thread is created that encompasses three rather than two scenes, and the figurative connections are multiplied. The resulting thread does not deliver a fixed meaning but rather, by positioning these incidents, invites the reader to partake in, and even delight in, the game of interpretation. Having dramatized his approach, Nabokov 
then declares: "The following of such thematic designs through one's life should be, I think, the true purpose of autobiography" (27). Durantaye observes of this sequence:

One thing that is highlighted here is a coldness and a callousness of tone. Another thing that is highlighted, or perhaps cancelled, is the importance of history. Although Nabokov fled not one but two totalitarian regimes, although he lost many of those dear to him to those regimes and their rippling effectsfrom his father's assassination in a lecture hall in Berlin to his brother Sergei's murder in a Nazi concentration camp-these events are noted with great reserve, and the larger historical forces that led to them go without analysis and are presented as though without interest. (Durantaye: 168)

The critic Will Norman notes of the same passage, "History... is literally derailed-its progress halted, its executors failed-while the pattern of images survives intact and static" (83; my ellipsis). According to Norman, Nabokov's project in Speak, Memory is aimed at "reclaiming the past in a constellated form," with the goal being to "bypass history" and "redeem the past" (83-4).

According to both these accounts the match stick theme is deployed to diminish or counteract history in favour of the artistic vision of an autobiographical past. Durantaye posits that this manoeuvre is performed successfully (168), while Norman points to its failure at crucial moments, as epitomised by the literary treatment of Nabokov's brother, Sergei, "a lacuna in Nabokov's conscious efforts at reading and coding the past" (Norman 89). Both critics take the position, however, that Speak, Memory is a book that breaks radically from its forbears in the autobiographical genre by foregrounding a structural and stylistic artifice. Durantaye draws on Jean-Jacques Rousseau as one of the "past masters" with whom Nabokov's offering can be contrasted (166). I too will use this comparison; however, my reading diverges from that of Durantaye in the outcome of this foregrounding of artifice in terms of the relationship of Speak, Memory to historical narrative: my argument being that rather than derailing history, Nabokov here performs a more nuanced action of both deferring to the power of historical narrative while also staking out a claim-one might take the "bombe of lemon sherbet" that he secretes away in his mouth when the Japanese trains are first mentioned (26) as a more concrete example of this-within it of the individual's experience in relation to the autobiographical act.

The culminating point of Durantaye's assessment, that the larger historical forces are presented without analysis, goes to the heart of Nabokov's method. I would argue to the contrary that while Nabokov does not explicitly pause the narrative to analyse the larger historical 
forces operating in this moment, a particular kind of dynamic analytical space, and therefore an implicit analysis, is being generated through play. This play occurs not just through juxtaposition and figurative language, but through word choice and tone. In returning to the matchstick and train passages, I point to the word, "pleases" as an example of this. This word, combined with the toy train image, suggests a passing childlike pleasure in patterns rather than the sustained interest of a scholar. Yet in the following line the scholarly tone is reasserted when Nabokov refers to: "the true purpose of autobiography" (27). In this way, and in combination with the more long-ranging dramatisation of play that comes from the combination of the three scenes using two figurative devices (the train and the match), both an adult and a child version of Nabokov's consciousness are projected in a technical approach that will also become a recurring feature of the book. Dabney Stuart offers an astute account of the technique:

Both the adult's consciousness at the time of writing and the child's consciousness at the time of playing coexist in the assembly of the recollection. Because of Nabokov's skill one experiences this dramatically, rather than being told about it. (179)

By performatively co-opting the spontaneous fascination of Nabokov the child into the measured eye of Nabokov the narrator, two narratives are upheld in a mutual tension; the childish repetition of a pattern that holds the naive eye of a child, against the account of the potential destruction of a man and the civilisation he emerged from. In all of these ways, the sense of play foregrounded in the match stick and train passages forms the basis for Nabokov's approach to the autobiographical project, an approach that has since become characteristic of the modern literary autobiographical project-in particular, the gesture by the autobiographical writer of inviting the reader into an interpretative or analytical space generated by the dynamic between the writer and his or her materials.

This factor points to a crucial distinction between literary and nonliterary memoir: while much of the current proliferation of popular autobiographical writing is comprised of the uncritical delivery of the individual's story as if it happened in just this way-rendering and validating the past with the particular authority of individual testimony-what distinguishes literary memoir, as exemplified by Nabokov's ground-breaking autobiographical project, is the continual restaging of crucial questions of agency, authenticity and authority in terms of personal experience. In brief, the literary memoirist is as much concerned with form as with material. Gunnthórunn Gudmundsdóttir observes the following of the relationship between autobiographical material and form: 
Narrative structure in autobiography can be seen as an attempt to order the chaos and confusion that is life. This presupposes what narrative theory has long maintained, that narrative is made up of two elements: fabula and sjuzet or histoire and discours. In the case of autobiography the fabula is comprised of the events of the life recounted and the sjuzet is then the order-or form-in which the events are recounted. (Gudmundsdóttir 59)

The dynamic between material and form, Gudmundsdóttir goes on to suggest (59), leads to an enduring question in both the study and the practice of autobiographical writing: does form enable us to discover the significance of events, or does it impose meaning upon those events? As Brockmeier and Carbaugh put it:

This is the question of whether there is, on the one hand, such a thing as pre-narrative experience, an original experience that is the unemplotted material of memory, so to speak, a kind of raw material on which the structures of narrative are being imposed a posteriori; or whether, on the other hand, our experience is from the very beginning organized in an inherently narrative fashion 14-15).

Nabokov's position in relation to this question may seem ambiguous or even contradictory-which perfectly represents the modern autobiographical project. On the one hand, he speaks of "following" thematic designs, as if they are there to be discovered. On the other hand, this noted student of chess puzzles continually dramatizes the sense of play that this process of discovery involves and leaves the interpretative process in the hands of the reader, thereby implying that form enables both the discovery of meaning and its imposition. In recent studies of the autobiographical text, form is generally considered to be the cohesion of all of the narrative strategiesstructural, figural, stylistic-that, depending on one's position in the above debate, either generate or extract the meaning from the material. Form, in the literary autobiographical text, always becomes to some extent contiguous with the author's analytical position in relation to the subject matter, and also to the question of discovery versus extraction. Form, in this context, has come to the fore just as the genre of "autobiography" has given way to the more fluid and expansive genre conception now covered by the term, "memoir." In The Cambridge Companion to Autobiography, Mary Cappello provides a neat summation of this movement:

The memoir, as we know, revolutionized autobiography by opening the genre to ordinary lives; by making memory itself autobiography's subject; by moving against the grain of linear narrative; by imagining the life as an endlessly discoverable reservoir of thematic traces rather than an event-driven, 
developmental chronology; by revaluing the daily, foregrounding the contemplative over the episodic, and reconceiving of meaning at the level of scale (minute particulars being as important as grand narratives) and at the level of time (moments and spots of time being as available to a memoirist's perception as historical markers, cataclysmic shifts, or years). (244)

Thus, literary memoir has transformed autobiography as genre both by a foregrounding of the authority of the writer as authentic generator of a text, and by laying bare the structural and stylistic designs that make this agency, and in particular its connection to a referential reality, more elusive. In retracing these moments in the development of life writing studies I align myself with the widely-though not universally-held contemporary view that they can now be equally related to the terms 'autobiography' and 'memoir.' As Maria Takolander puts it "every creative act is also shaped by its materials, drawing attention to how the self that materialises through the autobiographical artefact is always other than itself" (375). ${ }^{1}$

J. M. Coetzee notes that the Enlightenment writer Jean Jacques Rousseau, in his multi-volumed autobiographical work The Confessions, (17651767 and 1769-1770), which was first published in 1782, posthumously, creates and expounds an aesthetic approach that relies stylistically (therefore somewhat paradoxically) on a projection of rawness and spontaneity to break through the artifice of literary construction: a stylistically bolstered promise to write the self as thoroughly and clearly and honestly as possible. ${ }^{2}$ In contrast to Rousseau, Nabokov, writing on the other side of a chasm imposed by the trauma of early twentieth century history, has responded to the same challenge by emphasising, indeed leveraging, artifice through the structural and dramatic pursuit of the "thematic" pattern-hence carving out a position conspicuously at the opposite end of a spectrum that ranges, at its other extreme, to Rousseau's spontaneity. Admittedly, some may argue otherwise. ${ }^{3}$ Yet, in both instances, the writer's philosophy of the autobiographical process and its relationship to the past is explicated and foregrounded, exposed to the reader's gaze. It is this stance of self-explication vis-à-vis the reader-whether it is made explicit or conveyed implicitly through aesthetics, or indeed, if both of the above operate in tandem-that distinguishes literary memoir as a genre.

Given the self-awareness underpinning the construction of literary memoir, what Sidonie Smith, for example, terms its "self-reflexivity about the writing process," (4) it is likely (though not inevitable) that in this genre, when writers engage with historical events that are contemporaneous with the personal events depicted, when boundaries are inevitably crossed between public and private, the nature of this crossing and its portrayal also tends to become part of the memoir's story. The selfreflexivity of literary memoir tends to cast a broad illumination over all 
parts of the machinery and material that make up the autobiographical act, which involves not only the projection of an autobiographical self, but also the triangulation of that self within a societal and historical context.

What finds its way into the literary memoir project at every level as a result of this illumination, is the sense of play as much as remembering, expressed in one instance through Nabokov's dramatization of dual perspectives, which is expressed not only in the child/adult binary of perspective but also holds the public/historical alongside the private/recollected vantage point. Integral to the sense of play generated through these tensions is its purposeful inconclusiveness-for instance, as in Nabokov's playfully ironic title to the initial autobiographical project, Conclusive Evidence. This is the sort of play that generates ambiguity to invite the reader into an ongoing interpretative act in order to counteract and interrogate the declarative finality of implied testimony, whether on the grand historical scale or at the intimate level of the individual. It embodies both a dismissal and an affirmation of the individual whose life plays out against or within the grain of larger historical forces.

Here, it is necessary to return briefly to the description of the final encounter with the old Russian general in order to further illuminate the concept of play as employed by Nabokov. With the lines, "I hope old Kuropatkin, in his rustic disguise managed to evade Soviet imprisonment, but that is not the point," a neat inversion is performed of what the critic William Rowe refers to as Nabokov's widespread use of negation: "Essentially the device first denies one idea or image and then attempts to affirm a similar one" (3). Throughout his fiction and creative nonfiction, Nabokov makes regular use of this technique which, as Rowe points out, "owes part of its power to negative psychology and an element of briefly ensuing suspense" to create an effect in which the "initial, denied image, typically, lingers (3). This device, teasing out a sense of ambivalence through its simultaneity of affirmation and negation in the aesthetics of play, also links the idea of play even more explicitly to the aesthetics of staging, and is reliant on the reader's imaginative capacity to respond to cues of arrangement. However, in Speak Memory, Nabokov affirms (rather than denies) one thing - his hope that Kuropatkin has escaped the often life ending experience of Soviet imprisonment-only to deny (rather than affirm) it with the concluding clause of the sentence. Despite the inversion, the effect of the technique is similar; the dismissive end to the line is disrupted or infected by its beginning, that Kuropatkin's fate as an individual matters to Nabokov-or at least to the Nabokov constructed and projected within the text. The point here is that the concluding and the initiating statement pull at one another in an unresolvable tension. Building on the aesthetic thrust of Nabokov's inverted negation, the use of "I hope" leaves an ominous cloud over the general's head, implying 
that he may have vanished into the grim, anonymous fate of many of his fellow aristocrats, which he did not. According to the public record compiled at a time well before the writing of Nabokov's autobiographical work, Kuropatkin survived the rise to power of the Bolsheviks, taught at an agricultural school that he himself had founded, and, as one contemporaneous obituary noted, "died in his bed, unlike so many of his fellow countrymen who expiated their crime of patriotism by a violent death" (Knox, 168). Did Nabokov, the consummate researcher, avoid finding out the general's fate or did he avoid informing the reader? Thus, from this, it would seem that amplifying the effect of the inverse negation is likely a deliberate act of omission. The fictive arrangement of detail implying the general's grim outcome enables Nabokov to dramatize a connection between his personal experiences and the universal grind of history in which the civilisation as he knows it, and countless individuals within it, is destroyed. Even as, and arguably because, the exact details are skewed, there is "truth" in the moment. The moment, as it often does in Speak, Memory, is suspended against the larger, historical forces, much as the cradle, in his opening sentence of Chapter 1, "rocks above an abyss" (20). For the tension and the balance to be maintained in Nabokov's autobiographical method, the moment must not outshine the abyss.

Having used the matchbook theme to establish the value system by which his book is to be approached (1), Nabokov concentrates his aesthetic of the "pleasing" recurrence of patterns, and the dramatic counterbalancing of the childish, naïve perspective against the narrator's sense of artistic purpose, into a pair of sentences at the end of the chapter. Nabokov the child is sitting at the dining table, his attention focused through the framing device of a window onto what the narrator calls, "a marvellous case of levitation" (31). In accordance with local tradition, his father, having made a pleasing executive decision, is being thrown aloft by the peasants over whom he holds direct authority:

There, for an instant, the figure of my father in his wind-rippled white summer suit would be displayed, gloriously sprawling in mid-air, his limbs in a curiously casual attitude, his handsome, imperturbable features turned to the sky. Thrice, to the mighty heave-ho of his invisible tossers, he would fly up in this fashion and the second time he would go higher than the first and then there he would be, on his last and loftiest light, reclining, as if for good, against the cobalt blue of the summer noon, like one of those paradisiac personages who comfortably soar, with such a wealth of folds in their garments, on the vaulted ceiling of a church while below, one by one, the wax tapers in the mortal hands light up to make a swarm of minute flames in the mist of incense, and the priest chants of eternal repose, and funereal lilies conceal the face of whoever lies there, among the swimming lights, in the open coffin. (19) 
Brian Boyd, in writing of this moment, places heavy emphasis on Nabokov the autobiographical subject:

But he had learned from his parents to bear distress with dignity, and when he depicts his father high in the midday air he alludes to his private grief with the restraint taught him as a child (Boyd: 268).

Another critic, Galya Diment, compares the same moment to an incident later in the book when Nabokov's father avoids a duel. In that instance, Nabokov's childhood projected self spends a tense, evocative afternoon anticipating the possibility of his father's death, only to arrive home to discover the duel has been called off, and his parents standing on the stairs above him chatting light-heartedly with his uncle. As if he were the child speaking, and even though the level of verbal expression used is beyond that of a child's ability, Nabokov the narrator documents Nabokov the child's emotional reaction to the sight. In so doing, Nabokov the literary autobiographer negotiates the intersection of personal experience and history as the relationship between creative autobiographical process and historical narrative:

And then it happened: my heart welled in me like that wave on which the Buynïy rose when her captain brought her alongside the burning Suvorov, and I had no handkerchief, and ten years were to pass before a certain night in 1922, at a public lecture in Berlin, when my father shielded the lecturer (his old friend, Milyukov) from the bullets of two Russian Fascists and, while vigorously knocking down one of the assassins, was fatally shot by the other. But no shadow was cast by that future event upon the bright stairs of our St Petersburg house: the large, cool hand resting on my head did not quaver, and several lines of play in a difficult chess composition were not blended yet on the board. (Nabokov: 192)

In comparing this moment to the earlier incident, Diment observes:

The quick succession of the elevation to future tragedy and back to elevation and thus immortality is a reinforcement of a similar progression which occurred in chapter 1 with the scene of grateful peasants tossing V.D. Nabokov up in the air, in a traditional Russian show of enthusiastic approval. (179)

Both these instances can be viewed more richly through Nabokov's use of negation. In the second instance, though, the negation is particularly evocative. The shadow not being cast in the moment for the young Nabokov is, by implication, thrown for the reader. Further, by implication the reader is located in a vantage point that blurs the autobiographer's past and present; this vantage point contains the intersection of a private narrative 
and the historical record, the crossing of a boundary between private and public spheres. The incident referencing the Buynizy and Suvorov occurred during a naval battle in the Russo-Japanese war of 1904-1905. It was a catastrophic and shocking defeat for Russia that ended the war and undermined the Romanov dynasty, contributing both to the 1905 revolution and to the ultimate complete collapse of the old Russian order in 1917. In turn, this led to the disenfranchisement and exile of Nabokov's family and the assassination of his father, and even the death of his brother. Even though the war is in the background throughout Speak, Memory, it is also implicitly ever present, a force that punctures and interrupts key scenes. Its intricately patterned intersections with Nabokov's family serve as a constant reminder of the forces that have shaped not only Nabokov the writer, but his milieu. The most compelling aspect of the negation that Nabokov uses in Speak, Memory, is its evocation of larger historical forces through the structurally dismissive gesture of the brief reference or allusion that intersects with, or interrupts, the narrative present.

In this way, the image of Nabokov's father being tossed by the peasants at once gestures towards transcending the historical forces that will destroy his father, and shows the impossibility of such transcendence. The gesture is dramatized so that one simultaneously beholds its timeless and illusory quality, and its personal and public intersections. The father, calm, god-like, ultimately disempowered, trusting the immense force that tosses him up and down, surrenders to a dynamic tethered by the simile at the weighed-down close of the sentence, to his eventual fate. As Gudmundsdóttir observes, some autobiographies "might not tell us very much about specific historical events but they do shed light on the relationship between the individual and history in their time" (52). Here and throughout Speak, Memory, the technique of negation is part of a broader pattern of affirmation and negation that bridges the gap between personal experience (that is, sense making on an individual level,) and history by both dismissing history and affirming its impact on personal narrative.

In writing of Nabokov's relationship to history in Speak, Memory, and in order to situate it as a project against history in favour of the personal that is in the end partly defined by its moments of failure, Norman draws on a fictional short story, "The Visit to the Museum," which was published by Nabokov in 1938, during his exile in Paris. In this story, an unnamed protagonist visits a museum in order to retrieve a painting for an acquaintance. The painting is of the acquaintance's grandfather, which, as Norman observes, "has the effect of pitting a personal past against the official history" (95). During the course of the story, the director of the museum initially denies the existence of the painting, whereupon the narrator offers a bargain. If the painting is there, the narrator will purchase it for an agreed price. If the painting is not there, the narrator will hand 
over the money anyway. The director agrees to the bargain and records its terms in red pen. When the painting is confirmed as a verifiable fact, the trajectory of the narrative takes a nightmarish shift. The director inexplicably tears up the agreement and leads the narrator through the museum in an increasingly erratic manner. At the exact point when the narrator insists on ending the ordeal, the narrative slips completely into unreality:

At last, in a somber but magnificent room dedicated to the history of steam machines, I managed to halt my carefree guide for an instant.

"Enough!" I shouted. "I'm leaving. We'll talk tomorrow."

He had already vanished. ("Visit" 279)

The director, the bastion of authority in the "narrative" of the museum with its evocations of history, in the wafer thin gap between gesture and statement; at the exact moment he is apprehended by the narrator, when he should be most clearly graspable, vanishes. The narrator, untethered (to the order of the museum, to history), seeking only to withdraw, wanders through a series of increasingly hallucinatory experiences. At one point, in an indistinct, cavernous space full of fountains, at the centre of which lies a statue of Orpheus, he relates:

Now and then, on one side or the other, stone stairs, with puddles on the steps, which gave me a strange sensation of fear, would descend into misty abysses, whence issued whistles, the rattle of dishes, the clatter of typewriters, the ring of hammers, and many other sounds, as if, down there, were exposition halls of some kind or other, already closing or not yet completed. ("Visit" 279)

By this stage of the story, the inanimate has become full of threat. The puddles on the barely illuminated stairs may possibly be treacherous; the multiple references to "red" further allow the implication that the puddles may be blood. In the darkness on either side of these stairs, anonymous agents, who are presumably isolated from each other, are using tools such as hammers, whistles, dishes, and typewriters to make and erase, or record, history and experience. Slowly, in this hallucinatory chaos, everything visible is lost, until a red light (blood? suffering? Communism? a warning?) in the darkness pulls the narrator back into what seems to be "reality." The narrator finds himself in the Russia not of his past, but of the Stalinist present which his family avoided, and the substance of which he should therefore only be able to imagine. Yet the world is finely textured with concrete sensory detail. In this way an illusory framework is pitted against the rigid surface of reality. The narrator is at risk in this environment, and can only survive by blending in. Everything 
he carries indicates his otherness in this reality, yet to strip away all of this evidence will make him vulnerable in other ways, that is from cold, from exposed to the gaze of others. The narrator recounts himself standing in the snowy, hostile environment:

There were some documents, a letter from my sister in Paris, five hundred francs, a handkerchief, cigarettes; however in order to shed all the integument of exile, I would have to tear off and destroy my clothes, my linen, my shoes, everything, and remain ideally naked; and, even though I was already shivering from my anguish and from the cold, I did what I could. ("Visit" 281)

Norman sums up the scenario:

In "The Visit to the Museum" Nabokov articulates something that he is unwilling to elsewhere, that the "unreal trash: of "fool-made history" (Speak, Memory 234) to which he has always denied the status of reality leads inexorably to a present where that refusal cannot be so easily effected, in which the search for redemption may fail. (97)

There is a problem in this account. Norman's observations here invite unwarranted temporal blurring, and do not entirely account for the hallucinatory framework and subsequent inversions, of the protagonist's journey. The idea that Nabokov "has always denied the status of reality" to history, sidesteps the fact that Speak, Memory was completed long after the writing of "Visit to the Museum." The temporal issue would appear to be grammatical rather than actual, requiring merely the substitution of the present perfect with the future tense: "to which Nabokov will always deny the status of reality." However, this temporal blurring points to a larger effect implying that Nabokov articulates a position on history in this story that he fails to articulate in Speak, Memory. On the contrary, I would argue that his position in Speak, Memory is not only consistent with his approach in "The Visit to the Museum", but a development of it, and that, in both cases, there is not so much an articulation but rather a dramatization of this position.

A line near the opening of the story serves as an entry point for Nabokov's approach to history, and also for his approach to the relationship between form and material. Upon entering the museum, the narrator observes: "Everything was as it should be: gray tints, the sleep of substance, matter dematerialised" ("Visit" 274). Notably, the word "should" gains in resonance in a later phrase when combined with the narrator's reference to "vile conventionality" (in the depiction of the grandfather within the painting), and his question in relation to a collection of unidentified and inanimate lumps on display: "who decided, and why, that they merited 
a place in the museum?" ("Visit" 274). By the end of the story, everything is presumably, not as it should be: the inanimate has become full of threat, and speeds the narrator's passage into a location in time and space that, due to the abundance of sensory detail provided, appears to shed its illusory framework. However, the circumstances of the narrator's entry into this location cannot be forgotten, and linger in a tonal quality that governs the flawed logic in the protagonist's final actions (after all, if he does not wish to stand out, then stripping naked would surely be the wrong course of action), and in the narrator's final words in the story: "I have foresworn carrying out commissions entrusted one by the insanity of others" ("Visit" 281). There is in a sense here a fictive portrayal of the same technique of negation that will serve as the fulcrum between personal experience and history in Speak, Memory. That is, the existence of the painting is initially denied and then affirmed, and yet the dissolving structure of the story's reality following the verification of the painting's existence reinforces the initial denial rather than the affirmation. The painting - a personal, autobiographical artefact-both exists and does not exist, depending on one's vantage point, and the protagonist, initially free of the history around him, must ultimately defer to it. In a process that is implicit rather than explicated, and powerfully amplified by Nabokov's misdirection, the intimate, realistic, fictive observations of the final scene are undermined and, through this, foregrounded by their surreal context.

This outcome to the story, "The Visit," driven by its unresolved tension, its use of negation, and its misdirected final logic, finds its autobiographical counterpart in an episode at the heart of Chapter Two of Speak, Memory which neatly dramatizes the multiple issues and tensions that characterise the literary quest to excavate the autobiographical self from the historical moment. Much as the opening chapter of Speak, Memory hinges on a trick involving a handful of matches, the second chapter is constructed around an episode concerning a pencil that is much larger than it initially appears:

Presently, my mother came out of this shop followed by the footman. $\mathrm{He}$ carried her purchase, which looked to me like a pencil, and I was astonished that she did not carry so small an object herself. As she was being tucked up again in the sleigh, I watched the vapour exhaled by all, horse included. I watched, too, the familiar pouting movement she made to distend the network of her close-fitting veil drawn too tight over her face, and, as I write this, the touch of reticulated tenderness that my lips used to feel when I kissed her veiled cheek comes back to me-flies to me with a shout of joy. 
A few minutes later, she entered the room. In her arms she held a big parcel. It had been, in my vision, greatly reduced in size-perhaps because I subliminally corrected what logic warned me might still be the dreaded remnants of delirium's dilating world. (38)

Notable, in the above passage is the precision of the description, the vividness with which Nabokov constructs the childhood image. This is, again, a deceptively complex image based on a tension in the logic of its construction. There is confusion in the image, a blurring between scale and proportion; it is only the pencil, rather than the pencil and the person carrying it, that appears small when seen from a distance. Further to this blurring of proportion and scale, there is also-in the pattern repeated frequently in Speak, Memory-the blurring within one sentence of one image into other memories, and even into the writer's present. However, in the midst of this intense sensory sequence it is rather easy to forget the vantage point from which the first hand testimony occurs. Writes Nabokov earlier:

One day, after a long illness, as I lay in bed still very weak, I found myself basking in an unusual euphoria of lightness and repose. I knew my mother had gone to buy me the daily present that made those convalescences so delightful. What it would be this time I could not guess, but through the crystal of my strangely translucent state I vividly visualized her driving away. (37)

Thus, the part of the episode which concerns his mother's purchase of the pencil is, according to the text, merely an hallucination. The trick of perception - that he initially failed to recognise the size of the pencil-is itself rendered upon a bed of illusion or unreality. In relating the incident, Boyd notes: "Nabokov renders his vision so uncannily vividly and precisely that he seems to relive it now and allow us to relive it with him, as if we can transcend time and personality just as he seemed then to transcend space" (Boyd, 283). Crucially though, Boyd does not ask why. For example, is Nabokov suggesting that the project of evoking the parent becomes inextricably blurred with the project of maintaining or projecting a distinct autobiographical self? Is he cautioning against the deceptive power of the fictive elements in the autobiographical project and indeed in all recollections of the past up to an including the narratives of history? Is he suggesting that the attempt to be precise in recollection can have a distorting effect on what really happened, at least in the relation of one thing to another? Or is he, in a sense, inviting the reader to participate in the process of suggesting meaning within the tension between these possibilities? 
In Speak, Memory, as if to comment on his own use of technique Nabokov concludes the episode of the pencil "some years later", when he drills into the side of the pencil to ascertain that the graphite in the pencil runs all the way through, that there is no illusion in its presentation, that the pencil is "a perfect case of art for art's sake" (39). This drilling through the surface of a narrative object is a playful misdirection that both validates the incident and implicitly interrogates its delivery. After all, why end here? Why address and lay to rest the illusory potential of the object itself while leaving the deeper questions of perspective and form staged in the episode through the more profound illusion unanswered? Thus, at first glance, this chapter is about Nabokov's mother. On a deeper level, this chapter concerns that most fundamental of autobiographical questions, prefigured in "The Visit to the Museum", that goes to the heart of the autobiographical writer's authority and agency. Simply put, what does it mean to use the fictive elements of story telling to mediate personal experience against the broad sweep of historical narrative? The duality in Nabokov's approach to this problem once again rests on his use of negation and misdirection-that is, in the way he foregrounds artifice to generate a playful sense of ambiguity that encourages the reader to interrogate the relationship between the individual and their context.

It is in this light that the opening sentence of this particular chapter in Speak, Memory, sets the scene for his staging of perspective in autobiographical writing in both the private and the historical sense: "As far back as I remember myself (with interest, with amusement, seldom with admiration or disgust), I have been subject to mild hallucinations" (34). Importantly, the use of the word "seldom" indicates a tendency rather than an entirely consistent vantage point. It would seem that here, Nabokov is once again blurring the lines, stressing the role of play in the autobiographical project as he sees it. Rather than allowing judgement, whether positive or negative, to stifle his engagement with the past, Nabokov is driven by curiosity, and here the word "amusement" performs a similar role in its generation of unresolved tension as does the word "pleases" in the first chapter. The subject matter that is used to stage this question of perspective is the burden carried by those without power in Tsarist Russia.

This burden is represented figuratively by the monstrous pencil, initially held by the servant, which does not seem large to Nabokov until it is carried by his mother. There are also numerous minor details in the chapter that point to the burden more concretely. At one point, Nabokov relates how, if on family outings around the estate, a downpour came, then "old Dmitri would be sent to fetch the umbrella and raincoats from the house": and yet, "A quarter of an hour later he would reappear under a 
mountain of clothing in the vista of the long avenue which as he advanced would regain the leopard spots with the sun blazing anew and his huge burden unneeded" (42). Nabokov writes of his mother, "Not only were the kitchen and the servants' hall never visited by my mother, but they stood as far removed from her consciousness as if they were the corresponding quarters in a hotel" (45). The impression then is of a member of the aristocracy disconnected from the burdens that her life demands of others. In assessing his mother's blind spot, Nabokov writes, "And still later, when in exile, reviewing the past, she would often accuse herself (unjustly as I see it now) of having been less affected by the misery of man than by the emotional load man dumps upon innocent nature-old trees, old horses, old dogs" (47). Importantly, with Nabokov, word choice is crucial; a prime example of this is in his use of the word "unjustly" rather than "falsely," when referring to his mother's actions. It is worth noting too that Nabokov uses his illusory recollection of the pencil to implicate himself in his mother's limitations. Nabokov is focusing attention on the contradiction between one's perspective within the past and one's sense of a broader context outside of it, in the present-or the relationship between personal experience and historical narrative-as not an ethical concern but rather one inviting the reader's engagement with the notion of perspective itself.

By highlighting artifice in literary memoir, Nabokov mediates the tension between knowing and not knowing, or of seeing and not seeing, the dynamic region that expands infinitely between an imagined past and the illusory (or misleading) present integral to his autobiographical vantage point. The literary memoir is always an implicit negotiation of vantage point, a remembering on the one hand, that combines with a purposeful forgetting on the other. It is in this dynamic that the contingency of the border between fiction and fact can be found. In rendering our past selves at a particular moment in time, as in approaching all history, we cannot lose sight of everything we did not know within that vantage point - that is the essential truth of the past and indeed of history-it is also the driving force behind our imposition of meaning, and simultaneous extraction of meaning, in relation to past events. Once again, a pair of sentences at the end of Chapter Two round out Nabokov's argument regarding perspective:

It is certainly not then-not in dreams-but when one is wide awake, at moments of robust joy and achievement, on the highest terrace of consciousness, that mortality has a chance to peer beyond its own limits, from the mast, from the past and its castle tower. And although nothing much can be seen through the mist, there is somehow the blissful feeling that one is looking in the right direction. (Speak, Memory: 50) 
Here, Nabokov presents the ever-broadening gap between two vantage points of memoir; the one fixed in time-in Nabokov's case, his childhood self (his adult memories of his childhood experiences) - in some way impregnable and inaccessible, the other in motion, caught in the broad currents of a historical context that illuminates the past and throws its shadows into an imagined future, a life going forward into the unknown. When Nabokov remarks with deceptive lightness that "nothing much can be seen through the mist", he is describing the gap that he has already portrayed and staged, and through this, doubly acknowledging the limits of memory and autobiography, the way connections between past and present autobiographical selves rely on art, on trickery, a careful shaping of both what can be seen and what cannot, and the necessity of not allowing one's self to become fixed in place-the ultimate illusion bolstered by the illusory "present" of the text itself, reinforced as it is by the weight of the historical narrative vantage point-to become paralysed by certainty.

The use of artifice, exemplified by Nabokov's hyper-staging of artistic technique to dramatize and negotiate the relationship between personal experience and history, or personal and historical perspective, may be the most fundamental gift the memoirist can offer in the potentially dehumanising face of larger historical narratives. If Nabokov dismisses anything, it is the notion that the autobiographical self can be fully extracted from the clutches of history despite the artistic necessity of one's attempts. The extraction is always ongoing, an act of suspension "above the abyss," that generates its tension against the imposing cliff-face of history, like sparks struck in the darkness. In this way, he stakes out his claim towards one extreme of an autobiographical spectrum that ranges from artifice to spontaneity, a point of reference and illumination that most literary memoirists may only see from a distance as they negotiate for themselves, the precarious balance between autobiographical material and form: or personal experience (that is, sense making on an individual level) and historical narrative.

\section{WORKS CITED}

Boyd, Brian. Stalking Nabokov: Selected Essays. New York: Columbia UP, 2011.

Brockmeier, Jens, and Donal Carbaugh. "Introduction." Eds. Jens Brockmeier and Donal Carbaugh. Narrative and Identity: Studies in Autobiography, Self and Culture. Amsterdam: John Benjamins Pub, 2001 (1-22), https://ebookcentral-proquest-com.ezproxy.newcastle. edu.au/lib/newcastle/detail.action? docID =622888. Date accessed: 28 November 2017.

Cappello, Mary. "Wending Artifice." Eds. Maria DiBattista and Emily Wittman. The Cambridge Companion to Autobiography. Cambridge UP, 2014. 237-252. https://doi-org.ezproxy.newcastle.edu.au/10.1017/CCO9781139235686.021, doi:10.1017/CCO9781139235686.021. Date accessed: 25 February 2018. 
Coetzee, J. M. "Confession and Double Thoughts: Tolstoy, Roussea, Dostoevsky." Comparative Literature 37 (1985): 193-232, https://www-jstor-org.ezproxy.newcastle.edu.au/stable/1771079, doi: 10.2307/1771079. Date accessed: 20 January 2018.

Couser, Thomas. Memoir: An Introduction. New York: Oxford UP, 2012.

De La Durantaye, Leland. "Vladimir Nabokov and Sigmund Freud, or a Particular Problem." American Imago 62.1 (2005): 59-73. Project MUSE, doi:10.1353/aim.2005.0011.

De La Durantaye, Leland. "The True Purpose of Autobiography, or the Fate of Vladimir Nabokov's Speak, Memory." Eds. Maria DiBattista and Emily Wittman. The Cambridge Companion to Autobiography. Cambridge: Cambridge UP, 2014. https://doi-org.ezproxy.newcastle.edu.au/10.1017/CCO9781139235686.016, doi:10.1017/CCO9781139235686.016. Date accessed: 15 November 2017.

Gudmundsdóttir, Gunnthórunn. Borderlines: Autobiography and Fiction in Postmodern Life Writing. Amsterdam, New York: Rodopi, 2003.

Knox, Alfred. "General Kuropatkin.” The Slavonic Review 4 (June 1925): 164-168, https:// www.jstor.org/stable/4201935. Date accessed: January 11, 2018.

Nabokov, Vladimir. Speak, Memory: An Autobiography Revisited. New York: Vintage International, 1989.

Nabokov, Vladimir. "The Visit to the Museum." The Stories of Vladimir Nabokov. New York: Alfred A. Knopf, 1996. 273-281.

Norman, Will. "Nabokov and Benjamin: A Late Modernist Response to History." Ulbandus Review 10 (2007): 79-100. http://www.jstor.org/stable/25748166. Date accessed: 22 November 2017.

Rousseau, Jean Jacques. The Confessions (1765-1767 and 1769-1770). Geneva: Paul Moultou and Du Perron, 1782.

Rowe, William Woodin. Nabokov's Deceptive World. New York: New York UP, 1971.

Smith, Sidonie, and Julia Watson. Reading Autobiography: A Guide for Interpreting Life Narratives. 2nd ed. Minneapolis: University of Minnesota Press, 2001.

Stuart, Dabney. "The Novelist's Composure: Speak, Memory as Fiction." Modern Language Quarterly 36 (1975): 177-192, https://doi.org/10.1215/00267929-36-2-177. Date accessed: 21 September 2017.

Takolander, Maria. "Confessional Poetry and the Materialisation of an Autobiographical Self." Life Writing 14 (2017): 371-383, doi: 10.1080/14484528.2017.1337502, Date accessed 13 February 2017.

\section{ABOUT THE AUTHOR}

Michael Sala is an Australian Writer and Lecturer in English and Writing at the University of Newcastle, Australia. He has published numerous personal essays and articles, and written one memoir, The Last Thread (Affirm Press, 2012) which won the Glenda Adams/UTS Award for New Writing at the NSW Premier's Literary Awards, and was also the Pacific region winner of the Commonwealth Book Prize. His second book, The Restorer (Text Publishing, 2016) was short-listed in 2017 for the fiction prize in both the Victorian and the NSW Premier's Literary Awards, and longlisted for the Miles Franklin Literary Award. He is currently working on a third novel, due to be published with Text Publishing in 2020. E-mail: Michael.sala@newcastle.edu.au. Ph: (61) 49218811 . 


\section{Recent critical articles:}

'Knausgaard's My Struggle: The interplay of authority, structure, and style in autobiographical writing, Life Writing, Vol 15, Issue 2, 2016. DOI: $10.1080 / 14484528.2016 .1187989$.

\section{—http://dx.doi.org/10.1080/14484528.2016.1187989}

'Confession and third party revelation in memoir: The narrator, the confessant, and textual strategies for decentring the memoirist's authority', TEXT, Vol 17, No 2, 2013.

\section{—http://www.textjournal.com.au/oct13/sala.htm}

'Structure and struggle in book one of Karl Ove Knausgaard's My Struggle, in New and Experimental Approaches to Writing Lives, edited by Jo Parnell. London, UK: Macmillan International Higher Education (forthcoming Dec. 2018-early 2019).

\section{NOTES}

1 Knowing that portrayal is suspect, an act of fiction as much as recollection, the literary memoirist (re)negotiates the boundary between remembering and portrayal, while recognising the boundary's contingency, in order to tease out the ways in which what happened is simultaneously distorted and given shape by what can be made of it. Literary memoir draws its authoritative traction from the possibility of this distortion, (the unreliability of memory, the biases of perspective, the limitations of language) not only by using it as an engine for autobiographical portrayal, but also by making it the implicit subject of the analytical eye (See Takolander).

2 Coetzee notes: "The immediacy of the language Rousseau projects is intended as a guarantee of the truth of the past it recounts [...] it is a naive language that reveals the confessant in the moment of confession in the same instant that it reveals the past he confesses" (209).

3 Some may argue that it is less—or not only-Rousseau's spontaneity that Nabokov is opposing but the Freudian idea of an unconscious that structures the autobiographical discourse (see Coetzee; see also Durantaye 2005 and 2014). 